\title{
The future of seagrass meadows
}

\author{
CARLOS M. DUARTE* \\ IMEDEA (CSIC - UiB), C/ Miquel Marqués 21, 07190 Esporles, (Islas Baleares), Spain
}

Date submitted: 29 May 2001 Date accepted: 15 February 2002

\begin{abstract}
SUMMARY
Seagrasses cover about $0.1-0.2 \%$ of the global ocean, and develop highly productive ecosystems which fulfil a key role in the coastal ecosystem. Widespread seagrass loss results from direct human impacts, including mechanical damage (by dredging, fishing, and anchoring), eutrophication, aquaculture, siltation, effects of coastal constructions, and food web alterations; and indirect human impacts, including negative effects of climate change (erosion by rising sea level, increased storms, increased ultraviolet irradiance), as well as from natural causes, such as cyclones and floods. The present review summarizes such threats and trends and considers likely changes to the $\mathbf{2 0 2 5}$ time horizon. Present losses are expected to accelerate, particularly in South-east Asia and the Caribbean, as human pressure on the coastal zone grows. Positive human effects include increased legislation to protect seagrass, increased protection of coastal ecosystems, and enhanced efforts to monitor and restore the marine ecosystem. However, these positive effects are unlikely to balance the negative impacts, which are expected to be particularly prominent in developing tropical regions, where the capacity to implement conservation policies is limited. Uncertainties as to the present loss rate, derived from the paucity of coherent monitoring programmes, and the present inability to formulate reliable predictions as to the future rate of loss, represent a major barrier to the formulation of global conservation policies. Three key actions are needed to ensure the effective conservation of seagrass ecosystems: (1) the development of a coherent worldwide monitoring network, (2) the development of quantitative models predicting the responses of seagrasses to disturbance, and (3) the education of the public on the functions of seagrass meadows and the impacts of human activity.
\end{abstract}

Keymords: seagrass, conservation, status, perspectives, global change

\section{INTRODUCTION}

Seagrasses ecosystems are widely recognized as key ecosystems in the coastal zone, with important functions in the

* Correspondence: Professor Carlos M. Duarte Fax: +34 971 611761 e-mail: cduarte@uib.es marine ecosystem (Hemminga \& Duarte 2000). Yet, there is growing evidence that seagrass meadows are presently experiencing worldwide decline primarily because of human disturbance, such as direct physical damage and deterioration of water quality (Short \& Wyllie-Echeverria 1996; Hemminga \& Duarte 2000). There is, therefore, concern that the functions seagrasses have performed in the marine ecosystem will be reduced or, in some places, lost altogether. While efforts are being made to conserve seagrass ecosystems, these are not guided by a clear forecast of the changes expected and the threats to come. There is, therefore, a need for a prospective examination of the expected status of seagrass ecosystems in the future, which would provide guidance for the implementation of effective conservation policies. However, such an exercise requires reliable forecasts as to the expected progression of the relevant properties affecting the future status of seagrass ecosystems. Over the time horizon of 2025, there are estimates of human population growth and global climate change (Foundation for Environmental Conservation 2001), and the goal of this review is to provide a forecast of the likely status of seagrass ecosystems over that period. However, as Noble laureate Nils Bohr once stated, 'prediction is very difficult, particularly if it concerns the future', particularly given the many gaps in the present knowledge on the status of seagrass ecosystems. Hence, the future scenario depicted here should be considered as an ecological forecast, rather than a prediction, driven by the projected trends in the environmental factors that shape the seagrass habitat. While such forecasts must necessarily entail considerable uncertainty, their formulation requires a revision of our understanding of the response of seagrass ecosystems to a changing ecosystem that may help identify the areas where more robust knowledge is most needed. Hence, independently of the reliability of the forecast issued here, this review will deliver an identification of the research required to increase the reliability of the predictions about the response of seagrass ecosystems to a changing environment.

This review differs from previous attempts to forecast the future status of seagrass ecosystems in that these focused on their response to climate change (e.g. Brouns 1994; Beer \& Koch 1996; Short \& Neckles 1999), whereas the present exercise also considers the responses to the pressures derived from a growing human population. First, seagrasses and the functions they perform in the marine ecosystem are discussed together with their response to environmental forcing factors, 
including direct and indirect human impacts. Future threats and the consequences of seagrass loss are used to identify long-term trends and the likely status of seagrass meadows in 2025. This review concludes by discussing the managerial frameworks that must be implemented to anticipate the trends forecasted and optimize the conservation status of seagrass meadows by year 2025. Indeed, the forecast provided here reflects a projection from a 'business as usual' situation, whereas the adaptive nature of society to change, through the development of technologies and practices that minimize human impacts on the coastal environment, may render the forecasts issued here wrong. The required change of attitudes and technological developments may be, however, encouraged by the consideration of the future scenarios depicted here.

\section{SEAGRASSES AND THEIR FUNCTIONS IN THE ECOSYSTEM}

Seagrasses are angiosperms restricted to growth in marine environments. These plants evolved early in the history of angiosperms, but, unlike their land counterparts, showed a comparative evolutionary stasis (sensu Burt 2001), with their species richness being unlikely to exceed one hundred species at any one time through their evolutionary history (den Hartog 1970; Duarte 2001). All seagrass species are rhizomatous, clonal plants, occupying space through the reiteration of shoots, with their leaves and roots produced as a result of rhizome extension (Marbá \& Duarte 1998; Hemminga \& Duarte 2000). This asexual process appears to be the mechanism for seagrass proliferation, although some species such as Zostera marina (Olesen 1999) and Enhalus acoroides (Duarte et al. 1997a) reproduce a lot sexually, a mode of reproduction which is uncommon in some other species like Cymodocea serrulata and Posidonia oceanica (Hemminga \& Duarte 2000). Seagrass species vary about 100 -fold in growth rate and lifespan, which is inversely related to size (Duarte 1991a; Marbá \& Duarte 1998; Hemminga \& Duarte 2000).

Seagrasses require an underwater irradiance generally in excess of $11 \%$ of that incident in the water surface for growth, a requirement that typically sets their depth limit (Duarte 1991b). The upslope limit of seagrasses is imposed by their requirement for sufficient immersion in seawater or tolerable disturbance by waves and, in northern latitudes, ice scour (Hemminga \& Duarte 2000). Most seagrass species grow subtidally, although species within some genera such as Zostera spp., Phyllospadix spp. and Halophila spp. can grow intertidally (den Hartog 1970; Hemminga \& Duarte 2000). Seagrasses can grow in estuarine and brackish waters, but require salinity in excess of $5 \%$ to develop (Hemminga \& Duarte 2000). Although some species such as Phyllospadix spp. grow on rocky shores, most grow on sediments, ranging from sandy to muddy, with organic contents $<6 \%$ of the dry weight, sulphide concentrations $<300 \mu \mathrm{M}$ and redox potentials $>-100 \mathrm{mV}$ (Terrados et al. 1999; Hemminga \& Duarte 2000; Koch 2001).
Seagrasses form highly productive ecosystems, rivalling with the most productive biomes on earth (Duarte \& Chiscano 1999). Seagrass meadows generally occupy 0-30 m depth littoral fringes off all of the continents except Antarctica (den Hartog 1970). The global extent of seagrasses, although rather inadequately defined, is believed to be about $0.6 \times 10^{6} \mathrm{~km}^{2}$ (Charpy-Roubaud \& Sournia $1990)$, and their net production is about $0.6 \times 10^{15} \mathrm{gC} \mathrm{yr}^{-1}$ (Duarte \& Chiscano 1999), 15-50\% of which is allocated to the growth of below-ground organs (Duarte \& Chiscano 1999). Because of the large below-ground allocation of production, the generally low use of seagrass production by herbivores (Cebrián \& Duarte 1997), and the low decomposition rates of seagrass carbon (Harrison 1989; Enríquez et al. 1993), seagrasses store a large fraction of their substantial production, being responsible for about $15 \%$ of the carbon storage in the ocean (Duarte \& Cebrián 1996; Duarte \& Chiscano 1999). In addition, seagrasses also on average export $24.3 \%$ of their net production to adjacent ecosystems (Duarte \& Cebrián 1996), both to the land (e.g. Ochieng \& Erftemeijer 1999) and seaward (Menzies et al. 1967), acting as important trophic links with other ecosystems.

In addition to their high primary production, seagrasses perform many other functions in the ecosystem:

- Provision of food for coastal food webs,

- Provision of oxygen to waters and sediments,

- Carbon sequestration from the atmosphere,

- Organic carbon export to adjacent ecosystems,

- Sediment stabilization,

- Prevention of sediment resuspension,

- Improvement of water transparency,

- Wave attenuation,

- Shoreline protection,

- Habitat for microbes, invertebrates and vertebrates, often endangered or commercially important, and

- Trapping and cycling of nutrients.

These functions render seagrass meadows unique, ranking amongst the most valuable ecosystems in the biosphere, due to the important services they provide (Costanza et al. 1997).

\section{ENVIRONMENTAL FORCING FACTORS}

Because of the requirements of seagrass for adequate light and sediment conditions, they are affected by disturbances that modify the water and sediment quality. The seagrass shallow coastal environment is also particularly prone to physical disturbance, whether by waves or turbulence associated with strong storms (Preen et al. 1995; Poiner et al. 1989). Because disturbance is a sporadic phenomenon, seagrass meadows are highly dynamic ecosystems (e.g. Fourqurean \& Robblee 1999; Kendrick et al. 1999). These dynamics include widespread loss, such as the wasting disease that led to catastrophic die-back of eelgrass (Zostera marina) meadows on both sides of the Atlantic in the 1930s (den Hartog 1987), as 
well as more recent massive losses such as that in Florida Bay (Robblee et al. 1991), which is one of the largest areas of seagrass ecosystem worldwide (Fourqurean \& Robblee 1999). The causes and the possible role of human-derived impacts in such losses are still uncertain (cf. Hemming \& Duarte 2000). Strong disturbances, such as damage by hurricanes, can also lead to major seagrass losses (Preen et al. 1995; Poiner et al. 1989). Smaller-scale, more recurrent disturbances, such as that caused by the motion of sand waves in and out of seagrass patches (Marbá \& Duarte 1995) and that caused by large predators, such as dugongs (Nakaoka \& Aioi 1999), represent the main factor structuring some seagrass landscapes, which are characteristically patchy (Marbá \& Duarte 1995). In contrast, some seagrass species have been able to form long-lasting meadows, with meadows of the long-lived Posidonia oceanica dated to $>4000$ years old (Mateo et al. 1997), and single clones of Zostera marina dated, using molecular techniques at 3000 years old (Reusch et al. 1999).

In addition to natural variability of the seagrass habitat, human intervention is becoming a major source of change to seagrass ecosystems, whether by direct physical modification of the habitat by the growing human activity in the coastal zone (e.g. boating, fishing, construction; Walker et al. 1989), or through their impact on the quality of waters and sediments to support seagrass growth (Short \& WyllieEcheverria 1996; Hemminga \& Duarte 2000), as well as changes in the marine food webs linked to the seagrasses (Aragones \& Marsh 2000; Jackson 2001; Jackson et al. 2001).

\section{Human impacts}

Humans impact seagrass ecosystems, both through direct proximal impacts, affecting seagrass meadows locally, and indirect impacts, which may affect seagrass meadows far away from the sources of the disturbance (Table 1). Proximal impacts include mechanical damage and damage created by the construction and maintenance of infrastructures in the coastal zone, as well as effects of eutrophication, siltation, coastal engineering and aquaculture (Table 1; Fig. 1). Indirect impacts include those from global anthropogenic changes (Fig. 2), such as global warming, sea-level rise, $\mathrm{CO}_{2}$ and ultraviolet (UV) increase, and anthropogenic impacts on marine biodiversity, such as the large-scale modification of the oceanic food web through fisheries (Jackson 2001; Jackson et al. 2001). Indirect impacts are already becoming evident at present (e.g. Beer \& Koch 1996).

The most unambiguous source of human impact to seagrass ecosystems is physical disturbance. This susceptibility derives from multiple causes, all linked to increasing human usage of the coastal zone for transportation, recreation and food production. The coastal zone is becoming an important focus for services to society, since about $40 \%$ of the human population presently inhabit the coastal zone (Independent World Commission on the Oceans 1998). Direct habitat destruction by land reclamation and port construction is a major source of disturbance to seagrass meadows, due to dredging and landfill activities, as well as the reduction in water transparency associated with both these activities. The construction of new ports is associated with changes in sediment transport patterns, involving both increased erosion and sediment accumulation along the adjacent coast. These changes can exert significant damage on seagrass ecosystems kilometres away, which can be impacted by both erosion and burial associated with the changing sedimentary dynamics (e.g. Pascualini et al. 1999). The operation of the ports also entails substantial stress to the neighbouring seagrass meadows, due to reduced transparency and nutrient

Table 1 Impacts of direct and indirect human forcing on seagrass ecosystems.

\begin{tabular}{|c|c|c|c|}
\hline Type & Forcing & Possible consequences & Mechanisms \\
\hline \multirow[t]{7}{*}{ Direct impacts } & $\begin{array}{l}\text { Mechanical damage (e.g. trawling, } \\
\text { dredging, push nets, anchoring, } \\
\text { dynamite fishing) }\end{array}$ & Seagrass loss & $\begin{array}{l}\text { Mechanical removal and sediment } \\
\text { erosion }\end{array}$ \\
\hline & Eutrophication & Seagrass loss & Deterioration of light and sediment conditions \\
\hline & Salinity changes & $\begin{array}{l}\text { Seagrass loss, changes in community } \\
\text { structure }\end{array}$ & Osmotic shock \\
\hline & Shoreline development & Seagrass loss due to burial or erosion & Seagrass uprooting \\
\hline & Land reclamation & Seagrass loss & Seagrass burial and shading \\
\hline & Aquaculture & Seagrass loss & Deterioration of light and sediment conditions \\
\hline & Siltation & $\begin{array}{l}\text { Seagrass loss and changes in } \\
\text { community structure }\end{array}$ & Deterioration of light and sediment conditions \\
\hline \multirow[t]{5}{*}{ Indirect impacts } & Seawater temperature rise & Altered functions and distributions & $\begin{array}{l}\text { Increased respiration, growth and flowering, } \\
\text { increased microbial metabolism }\end{array}$ \\
\hline & Increased $\mathrm{CO}_{2}$ concentration & $\begin{array}{l}\text { Increased depth limits and } \\
\text { production }\end{array}$ & $\begin{array}{l}\text { Increased photosynthesis, eventual decline of } \\
\text { calcifying organisms }\end{array}$ \\
\hline & Sea level rise and shoreline erosion & Seagrass loss & Seagrass uprooting \\
\hline & Increased wave action and storms & Seagrass loss & Seagrass uprooting \\
\hline & Food web alterations & Changes in community structure & $\begin{array}{l}\text { Changes in sediment conditions and } \\
\text { disturbance regimes }\end{array}$ \\
\hline
\end{tabular}




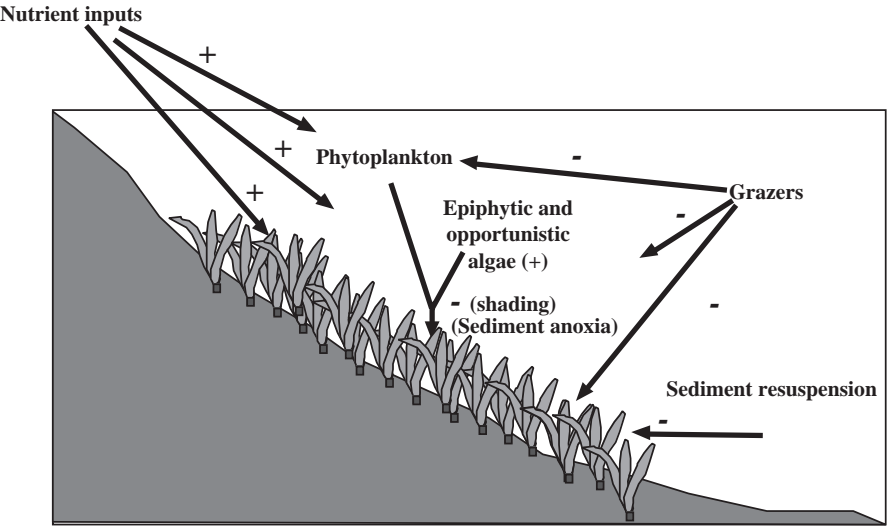

Figure 1 Effects of eutrophication derived from increased nutrient loading on seagrass ecosystems. Positive and negative indicate the sign of the effects. Chained positive and negative effects affect seagrasses negatively, whereas chained negative effects affect seagrasses positively.

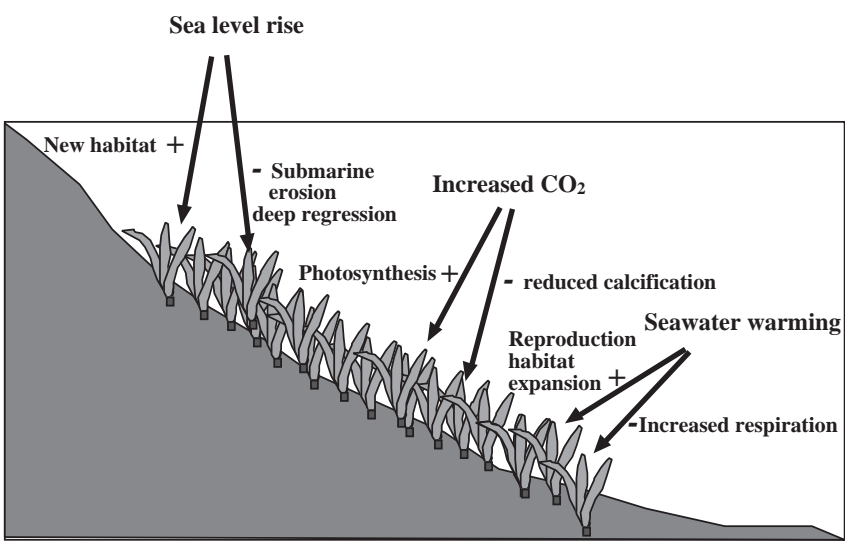

Figure 2 Forecasted effects of climate change on seagrass ecosystems. All components include positive and negative effects.

and contaminant inputs associated with ship traffic and servicing, as well as dredging activities associated with port and navigation-channel maintenance. Rapid increases in seabased transport, as well as recreational boating activities have led to a major increase in the number and size of ports worldwide (Independent World Commission on the Oceans 1998), with a parallel increase in the combined disturbance to seagrass meadows. Ship activity also causes disturbance to seagrass through anchoring damage, which can be rather extensive at popular mooring sites (Walker et al. 1989), as well as fisheries operation, particularly shallow trawling (Ramos-Esplá et al. 1993; Pascualini et al. 1999) and smallerscale activities linked to fisheries, such as clam digging and use of push nets over intertidal and shallow areas and, in extreme cases, dynamite fishing (Kirkman \& Kirkman 2000). The exponential growth of aquaculture, the fastest-growing food production industry, has also led to impacts on seagrasses through shading and physical damage to the seagrass beds, as well as deterioration of water and sediment quality leading to seagrass loss (Delgado et al. 1997, 1999; Pergent et al. 1999; Cancemi et al. 2000).

The coastal zone also supports increasing infrastructure, such as pipes and cables for transport of gas, water, energy and communications, deployment and maintenance of which also entail disturbance to adjacent seagrass meadows. The development of coastal tourism, the fastest-growing industry in the world, has also led to a major transformation of the coastal zone in areas with pleasant climates. For instance, about two-thirds of the Mediterranean coastline is urbanized at the present time, with this fraction exceeding $75 \%$ in the regions with the most developed tourism industry (UNEP [United Nations Environment Programme] 1989), with harbours and ports occupying $1250 \mathrm{~km}$ of the European Mediterranean coastline (European Environmental Agency 1999). Urbanization of the coastline often involves destruction of dunes and sand deposits, promoting beach erosion, a major problem for beach tourism. Beach erosion, however, does not only affect the emerged beach, and is usually propagated to the submarine sand colonized by seagrass, eventually causing seagrass loss (Medina et al. 2001). Groynes constructed to prevent beach erosion often create extensive problems, by altering longshore sediment transport patterns, further impacting the seagrass ecosystem. Extraction of marine sand for beach replenishment is only economically feasible at the shallow depths inhabited by seagrasses, which are often impacted by these extraction activities (Medina et al. 2001). The threats coastal tourism poses to seagrasses are sometimes direct, as in some cases of purposeful removal of seagrass from beach areas to 'improve' beach conditions. Fortunately, there are indications that coastal tourism is attempting, at least in some areas, to embrace sustainable principles, including the maintenance of ecosystem services, such as those provided by seagrasses, and could well play a role in the future as an agent pressing for seagrass conservation.

Widespread eutrophication of coastal waters (Vidal et al. 1999) derived from the excessive nutrient input to the sea, is leading to global deterioration in the quality of coastal waters (Cloern 2001), which is identified as a major loss factor for seagrass meadows worldwide (Duarte 1995; Short \& WyllieEcheverria 1996; Hemminga \& Duarte 2000). Human activity presently dominates the global nitrogen cycle, with anthropogenic fixation of atmospheric nitrogen now exceeding natural sources (Vitousek et al. 1997), and anthropogenic nitrogen now dominating the reactive nitrogen pools in the atmosphere, and therefore rainwater, of industrialized and agricultural areas (Nixon et al. 1996). Hence, anthropogenic nitrogen dominates the nitrogen inputs to watersheds, with the human domination of nitrogen fluxes being reflected in a close relationship between nitrate export rate and human population in the world's watersheds (Cole $e t$ al. 1993). Tertiary water-treatment plants only achieve a partial reduction in nitrogen inputs to the sea, for nitrogen inputs to the coastal zone are already dominated by direct 
atmospheric inputs in heavily industrialized or agricultural areas (Paerl 1995).

Although seagrass meadows are often nutrient limited (e.g. Duarte 1990), increased nutrient inputs can only be expected to enhance seagrass primary production at very moderate levels at best (Borum \& Sand-Jensen 1996). Whereas seagrasses, through their low nutrient requirements for growth and their high capacity for internal nutrient recycling (Hemminga \& Duarte 2000), are well fitted to cope with low nutrient availability, other primary producers, both micro- and macroalgal, are more efficient, because of greater affinity and higher uptake rates, in using excess nutrient inputs (Duarte 1995; Hein et al. 1995). Coastal eutrophication promotes phytoplankton biomass, which deteriorates the underwater light climate, and the stimulation of the growth of epiphytes and opportunistic macroalgae, which further shade and suffocate seagrasses (Duarte 1995; den Hartog 1994; Hemminga \& Duarte 2000; Hauxwell et al. 2001). The alleviation of nutrient limitation, together with the proliferation of phytoplankton and epiphyte biomass as a result of increased nutrient inputs imply that coastal eutrophication leads to a shift from nutrient limitation to light limitation of ecosystem production (Cloern 2001), enhanced through competitive interactions between different types of primary producers for light (Sand-Jensen \& Borum 1991; Duarte 1995). These effects result in seagrass loss, particularly in the deeper portions of the meadows (Sand-Jensen \& Borum 1991; Duarte 1995; Borum 1996). Heavy grazing, which can buffer the negative effects of eutrophication, may attenuate the effects of overgrowth by phytoplankton, epiphytes and macroalgae (cf. Heck et al. 2000; Hemminga \& Duarte 2000). Eutrophication may, furthermore, have negative effects directly derived from the high resulting nutrient concentration, for high nitrate and ammonium concentrations may be toxic to seagrasses (e.g. Van Katwijk et al. 1997).

Whereas research on the effects of eutrophication on seagrass meadows has focused on the effects of reduced light quality (Duarte 1995), the deterioration of the sediment conditions may also play a critical role in enhancing the loss of seagrasses. Seagrass sediments are typically rich in organic materials, due to the enhanced particle deposition and trapping under seagrass canopies (Terrados \& Duarte 1999; Gacia \& Duarte 2001) compared to adjacent bare sediments. Microbial processes are, therefore, stimulated in the seagrass rhizosphere (Hemminga \& Duarte 2000), which, if sufficiently intense, lead to the depletion of oxygen and the development of bacterial communities with anaerobic metabolism, which release by-products, such as sulphide and methane, that may be toxic to seagrasses (e.g. Carlson et al. 1994; Terrados et al. 1999). In order to avoid such toxicity effects, seagrasses pump a significant fraction of the photosynthetic oxygen produced to the roots, which release oxygen to maintain an oxidized microlayer at the root surface (Pedersen et al. 1998). However, eutrophication reduces seagrass primary production both through shading and seagrass loss, thereby reducing the oxygen seagrass roots may release. This allows anaerobic processes and the resulting metabolites to accumulate closer to the root surface, increasing the chances of toxic effects to seagrass. At the same time, the increased pelagic primary production leads to a greater input of organic matter to the sediments, enhancing microbial activity and the sediment oxygen deficit, which may increase the production of metabolites from anaerobic microbial metabolism. Both these processes result in the deterioration of the sediment environment to support seagrass growth, leading, through its interaction with the consequences of reduced light availability, to accelerated seagrass loss (Hemminga \& Duarte 2000). Eutrophication effects on sediments may be more acute where sewage is the dominant source of nutrients, for this is discharged along with a high organic load, stimulating microbial activity (Jorgensen 1996). Aquaculture activities are becoming increasingly prominent in the shallow, sheltered coastal waters where seagrass meadows abound. Shading and high inputs of organic matter from fish cages have been shown to lead to seagrass decline below and around fish cages (Delgado et al. 1997, 1999; Pergent et al. 1999, Cancemi et al. 2000), through processes comparable to those of the eutrophication outlined above.

Increased siltation of coastal waters is also a major human impact on seagrass ecosystems, which derives from changes in land use leading to increased erosion rates and silt export from watersheds. Siltation is a particularly acute problem in South-east Asian coastal waters, which receive the highest sediment delivery in the world as a result of high soil erosion rates derived from extensive deforestation and other changes in land use (Miliman \& Meade 1993). Siltation severely impacts South-east Asian seagrass meadows through increased light attenuation (Bach et al. 1998) and burial (Duarte et al. 1997b), leading to seagrass loss and, where less intense siltation occurs, a decline in seagrass diversity, biomass and production (Terrados et al. 1998).

Large-scale coastal engineering often alters circulation and salinity distributions, leading to seagrass loss. Hence, seagrass meadows, previously abundant in Dutch coastal areas, are now much reduced in surface, partially related to shifts of coastal waters from marine to brackish or freshwater regimes (e.g. Nienhuis et al. 1996).

Pollution, other than that from nutrients and organic inputs, may be an additional source of human impacts on seagrass ecosystems, although, seagrass appears to be rather resistant to pollution by organic and heavy metal contaminants (Hemminga \& Duarte 2000). These substances may possibly harm some components of the seagrass ecosystem, although such responses have not been examined to a significant extent.

Human activity in the coastal zone has greatly impacted biodiversity at regional scales, whether by removing or adding species. These changes to marine biodiversity impact food webs and competitive interactions between organisms, directly and indirectly affecting seagrass beds (Jackson 2001; Jackson et al. 2001). Hunting has led to a major decline in the 
abundance of dugongs and sea turtles, which are agents of small-scale disturbance influencing the structure and dynamics of seagrass ecosystems (e.g. Aragones \& Marsh 2000). Indeed, there is concern that the depletion of dugong and sea turtle populations to levels where they can no longer exert an impact at the basin scale, may lead to major shifts in seagrass community structure, with the decline of the species dependent on recurrent small-scale disturbance, such as a Halophila spp. (Preen 1995; De Iongh 1996). These concerns stem from evidence from the fossil record that extinctions within the one diverse syrenid fauna were associated with extinctions of seagrass species (Domning 2001). It has been suggested recently that the decline in mega-grazers may have caused an increase in organic matter deposition in seagrass sediments, possibly explaining recent large-scale decline of seagrasses in systems such as Florida Bay, USA, and Moreton Bay, Australia (Jackson 2001; Jackson et al. 2001). However, the evidence to suggest that the loss of megagrazers results or has resulted in a deterioration of habitat conditions to support seagrass is meagre at best (Jackson 2001; Jackson et al. 2001), so that these suggestions should be considered as interesting hypotheses pending confirmation, rather than established facts. In addition, high grazing pressure in the past, such as implied by this hypothesis, stresses the plants and ultimately results in a decline of leaf production, which has been ascribed to a depletion in the sediment nutrients available for plant growth (Zieman et al. 1984).

Global trade has increased the mobility of marine species, whether purposely, such as aquarium specimens, or inadvertently, such as organisms carried in ballast waters. The increased human-mediated transport of species between geographically distant locations has increased the incidence of invasive species. A case affecting Mediterranean, and probably soon Eastern Pacific seagrasses, is the invasion of the Mediterranean by the tropical algal species Caulerpa taxifolia, which first invaded the French Mediterranean in the early 1980s, apparently released from an aquarium, and has been reported to have expanded since along the French coast to reach the Italian and Spanish (Majorca Island) coasts (Meinesz \& Hesse 1991). C. taxifolia grows rapidly and appears largely to colonize areas devoid of seagrasses, but has been reported to compete for space and resources with Posidonia oceanica off Monaco (Meinesz \& Hesse 1991), being able to damage the Posidonia oceanica meadows, particularly when these are already under stress (de Villéle \& Verlaque 1995; Jaubert et al. 1999). The species has recently been reported on the Californian coast, raising concerns that it could also cause problems for the seagrass beds there. The Mediterranean Sea has also been invaded by Halophila stipulacea (Biliotti \& Abdelahad 1990), across the Suez Canal, but no damage to the local seagrass meadows has been reported.

Direct or indirect human intervention locally causes most impacts. However, at the regional or global scale, human activity also exerts an important impact on seagrass ecosystems. These effects are remarkably difficult to separate from responses to background natural changes in the highly dynamic coastal ecosystem. These impacts involve the effects of the realized and predicted climate change (Table 1), and result from changes in sea level, water temperature, UV irradiance, and $\mathrm{CO}_{2}$ concentration.

The mean global sea level has risen about $10-25 \mathrm{~cm}$ over the 20th century, which should have generated an average recession of the global coastline by 10-25 m (Bruun 1962), and, therefore, a large-scale erosion of shallow marine sediments. There is little doubt that such changes must have affected seagrasses, which are very sensitive to sediment erosion (e.g. Marbá \& Duarte 1995), although there is little or no direct observational evidence for these changes. The effects on seagrasses of seawater warming of $0.3-0.6{ }^{\circ} \mathrm{C}$ over the 20th century (Mackenzie 1998) are generally less evident than those produced by sea-level changes. Temperature affects many processes that determine seagrass growth and reproduction, including photosynthesis, respiration, nutrient uptake, flowering and seed germination (Short \& Neckles 1999). Although observations of increased flowering frequency of Posidonia oceanica in the Mediterranean have been tentatively linked to the seawater temperature increase (Francour et al. 1994), there is little evidence at present to suggest any impact of increased temperature as a result of global warming. The temperature increase may further impact seagrass ecosystems through effects on other components, such as an increased respiratory rate of the associated microbial communities. Stimulation of microbial respiration would further enhance the problems derived from high organic inputs to seagrass sediments (Terrados et al. 1999). Summer UV irradiance has greatly increased at high latitudes, and an increase in the north-temperate zone is also becoming evident. Increased UV levels are expected to impact negatively shallow, particularly intertidal, seagrasses (Dawson \& Dennison 1996). The photosynthetic rates of light-saturated seagrass leaves are often limited by the availability of dissolved inorganic carbon, and, since the concentration of $\mathrm{CO}_{2}$ in well-mixed, shallow coastal waters is in equilibrium with the atmosphere, the increase in atmospheric $\mathrm{CO}_{2}$ concentration by $25 \%$, from $290 \mathrm{ppm}$ to $360 \mathrm{ppm}$, over the 20th century (Mackenzie 1998), may have led to an increase in light-saturated seagrass photosynthesis by as much as 20\% (recalculated from information in Brouns 1994 and Beer \& Koch 1996). There is, however, little evidence that such physiological responses have led to observable changes in seagrass ecosystems at present.

\section{Natural versus anthropogenic influences}

Some cause-effect relationships between local seagrass loss and direct human activities, such as increased nutrient and organic loading, constructions on the coastline or boating activity, can be readily demonstrated. For instance, the loss of Zostera marina in a bay on the Atlantic coast of the USA has been shown to be closely correlated to housing 
development (Short \& Burdick 1996). However, the link between seagrass losses and indirect human influences is more elusive, since the coastal zone is a highly dynamic ecosystem, where many conditions vary simultaneously. Disturbances such as strong storms, hurricanes and typhoons, severely impact seagrass beds, to the point that they may be essential components of the dynamics of seagrass meadows (Duarte et al. 1997b). The difficulties of discriminating between sources of seagrass loss are best illustrated by example. A wasting disease decimated Zostera marina meadows in the 1930s on both sides of the Atlantic. The proximal cause for the loss seems to have been an infection by a fungus, Labyrinthula zosterae, although it may have affected Zostera marina meadows that were already stressed (den Hartog 1987). Hypotheses to account for this widespread loss also point to natural changes, such as unusual seawater warming, as possible triggers for the decline (den Hartog 1987). Whether indirect human impacts on global processes may have played a role remains untested. The causes for the more recent loss of vast areas of seagrass, mostly Thalassia testudinum, in Florida Bay (Robblee et al. 1991) continue to be debated, and include, among others, increased anthropogenic nutrient loading, the effects of climatic changes involving a long time interval without hurricanes affecting the area also causing unusually low freshwater discharge (Fourqurean \& Robblee 1999; Zieman et al. 1999), and the effects of the increased accumulation of detritus derived from loss of mega-grazers (Jackson 2001; Jackson et al. 2001). Difficulties in experimenting at the appropriate scale of whole meadows to test these hypotheses have precluded elucidation of whether the decline was due to human or natural causes, or a combination of both.

The challenge lies, therefore, in separating local loss processes, which would suggest a local, likely humanderived, source of disturbance, from indirect effects, both natural and anthropogenic, acting at a much larger spatial scale. The ability to reconstruct the growth history of the long-lived Mediterranean seagrass Posidonia oceanica allowed the examination of the coherence of past growth patterns along the Spanish Mediterranean coast (Marbá \& Duarte 1997). This examination revealed coherent growth patterns in populations $200-300 \mathrm{~km}$ along the coast, as well as a general tendency towards a decline in vertical growth, which indicates a tendency towards sediment erosion (Marbá \& Duarte 1997). These trends were present even in meadows distant from any identifiable human disturbance, and were related to decadal changes in climate (Marbá \& Duarte 1997).

Hence, despite clear signals of anthropogenic effects on climate components, the responses of the seagrass ecosystem are still unclear, probably due to the still modest size of the changes experienced but also, and perhaps to a greater extent, to the lack of adequate long-term monitoring systems allowing the detection of responses in the seagrass ecosystem.

\section{Future threats}

Future threats to seagrass meadows evolve from the development and expansion of those threats already operating. Increasing human use of the coastal zone predicates an uncertain future for seagrass meadows. Coastal populations, both resident and tourist, continue to grow rapidly, with those in the Mediterranean doubling at 30-year and 15-year intervals, respectively (UNEP 1989). Increased human activity in the coastal zone is associated with increased physical disturbance of seagrass meadows, through the construction of coastal infrastructures, and increased boating and shipping. Aquaculture is growing exponentially worldwide (World Resources Institute 1998), and parallel depletion of natural fish populations should lead to a maintenance, or even acceleration, of the expansion of coastal aquaculture, with associated potential impacts on seagrass meadows. The present trend towards increasing per caput water use, the expansion of waterborne sewage systems, and the growing use of fertilizers (World Resources Institute 1998) should lead to increasing nutrient and sewage discharge to coastal waters, and therefore a further expansion of the already widespread eutrophication problems. Although sewage treatment is also growing, the volume treated is growing much more slowly than that of total sewage and nutrient discharge (Nixon 1995). Similarly, there are no symptoms that land-use changes and deforestation are declining in the developing world, so that associated problems, such as siltation of coastal waters (see above), are likely to continue to increase in the future.

The extent of indirect human impacts on seagrass ecosystems should also increase in the future, due to increasing emissions of $\mathrm{CO}_{2}$ and other greenhouse gases. These activities should lead to an increase in the concentration of $\mathrm{CO}_{2}$ in seawater, with a resulting decline in seawater $\mathrm{pH}$ (e.g. Kleypas et al. 1999), increased water temperature, and sealevel rise, together with an increased frequency of storms and wave action (Carter 1988; Bijlsma et al. 1996). Whereas an increase in the concentration of $\mathrm{CO}_{2}$ in seawater may have positive effects on seagrass photosynthesis, possibly enhancing seagrass primary production worldwide, the decline in seawater $\mathrm{pH}$ should negatively affect calcifying organisms (Kleypas et al. 1999), including those present in seagrass meadows. The increasing sea level and storm activity (Carter 1988; Bijlsma et al. 1996) should be conducive to increasing coastal erosion and subsequent loss of seagrass meadows. Sea-level rise leads to a recession of the coastline, which can be roughly estimated as a horizontal recession rate of 100 times the consolidated sea-level rise (applying Bruun's 1962 rule of $1 \mathrm{~m}$ recession per $\mathrm{cm}$ increase in sea level).

Sea-level rise creates, in the long term, new habitat for seagrass growth, which should lead to colonization of the inundated land, although the rates of sea-level rise are too slow to allow direct observation of the progression of the upslope limit of seagrass distribution; however, consideration of the sea-level rise of $10-25 \mathrm{~cm}$ over the 20th century 
suggests the inundation (applying Bruun's 1962 rule) of $10-25 \mathrm{~m}$ of land, with an equivalent potential upslope progression of the vegetation. The downslope limit of the seagrass, which is generally set by the water transparency (Duarte 1991b), is likely to experience a similar upslope regression (i.e. $1-2.5 \mathrm{~m}$ horizontally $\mathrm{yr}^{-1}$ ): this assumes the transparency to remain constant, so that the bathymetric range occupied by seagrasses should not necessarily increase with the colonization of new inundated areas upslope. These processes introduce a dynamic perspective on the upslope and downslope distribution of seagrass meadows, which needs be considered in monitoring programmes, which may interpret the expected horizontal regression of $1-2.5 \mathrm{~m}$ per decade at the downslope limit as decline, when it may well represent a readjustment of the entire meadow to sea-level rise.

\section{Consequences of seagrass loss}

Seagrass loss leads to a loss of the associated functions and services in the coastal zone. The consequences of seagrass loss are well documented, through observations of the changes in the ecosystem upon large-scale seagrass losses (Hemminga \& Duarte 2000). Seagrass loss involves a shift in the dominance of different primary producers in the coastal ecosystem, which can only partially compensate for the loss of primary production. For instance, the increased planktonic primary production with increasing nutrient inputs does not compensate for the lost seagrass production, so that there is no clear relationship between increased nutrient loading and ecosystem primary production (Borum 1996). The loss of the sediment protection offered by the seagrass canopy enhances sediment resuspension, leading to a further deterioration of light conditions for the remaining seagrass plants (Olesen 1996). The extent of resuspension can be so severe following large-scale losses, such as that experienced during the Zostera marina wasting disease, that the shoreline may be altered (Christiansen et al. 1981). The loss of seagrasses will also involve the loss of the oxygenation of sediment by seagrass roots, promoting anoxic conditions in the sediments. Seagrass loss has been shown to result in significant loss of coastal biodiversity, leading to a modification of food webs and loss of harvestable resources (Young 1978; Hemminga \& Duarte 2000). In summary, seagrass loss represents a major loss of ecological as well as economic value to the coastal ecosystems, and is therefore, a major source of concern for coastal managers.

\section{IDENTIFIED LONG-TERM TRENDS}

Whereas records of change in seagrass ecosystems are few, the existing reports point to a tendency for widespread decline in both temperate and tropical ecosystems. There have been reports of large-scale seagrass decline at over 40 locations (Hemminga \& Duarte 2000), 70\% of which were unambiguously attributable to human-induced disturbance (Short \& Wyllie-Echeverria 1996), and reports of seagrass loss have multiplied by 10 in the last decade, which can only partially be accounted for by the increased effort in seagrass research and monitoring (Duarte 1999). Whereas some recovery has been demonstrated (e.g. Kendrick et al. 1999; Preen et al. 1995), most records indicate this to be either nonexistent or incomplete, so that the perceived long-term trend of seagrass points to a global decline, the extent of which is largely unknown. Short and Wyllie-Echevarria (1996) estimated, extrapolating from the reports available, the area of seagrass meadows globally lost during the 1990s at about $12000 \mathrm{~km}^{2}$, corresponding to the loss during this period alone of about $2 \%$ of the area originally covered by seagrasses.

There is mounting evidence that Posidonia oceanica, which was estimated to cover about $50 \quad 000 \mathrm{~km}^{2}$ in the Mediterranean (Bethoux \& Copin-Montégut 1986), has been suffering widespread decline, at least in the north-west Mediterranean (Marbá et al. 1996; Pascualini et al. 1999; Boudouresque et al. 2000). An analysis of the age structure of Posidonia oceanica meadows in the Spanish Mediterranean showed a tendency for decline in $57 \%$ of the meadows examined (Marbá et al. 1996). Whereas some of those meadows still persist, some others have already been lost (C.M. Duarte, unpublished results 1999). The loss is not evenly distributed along the Spanish Mediterranean, but is concentrated in approximately $400 \mathrm{~km}$ of coastline, where only traces of some meadows recorded in the late 1980s remain and many have been lost already (C.M. Duarte, unpublished results 1999). Whereas local human impacts are often evident as causes for the decline of Posidonia oceanica meadows, this is not always the case, and, together with significant correlations between decadal growth and climate variation (Marbá \& Duarte 1997), points to climate change effects and possibly indirect human impacts on the observed decline. For instance, the gradual decline in Zostera marina growing in the French coast noticed during the 1980s and 1990s was also related to elevated sea-surface temperatures observed since the 1980s (Glémarec 1997). These observations suggest that seagrass decline and, possibly expansion, may be triggered by large-scale climate change (Fig. 2). If so, rapidly changing climatic patterns may lead to major changes in seagrass cover in the future.

Along the Danish coast, eelgrass has shown an important net reduction in cover over the 20th century, with important declines (die-off in the 1930s), rebounds and secondary declines, in between (P.B. Christensen, D. Krause-Jensen \& J. S. Laursen, unpublished data 2000). These observations portray eelgrass ecosystems as highly dynamic at time scales longer than decadal. If undisturbed, seagrass communities can be rather stable, with records of continuous presence of specific seagrass beds for several millennia (e.g. Zostera marina, Reusch et al. 1999; Posidonia oceanica, Mateo et al.1997), and the extent and time scales of fluctuations in seagrass meadows may differ greatly across species and locations. 


\section{POTENTIAL STATUS IN 2025}

The prospective trends in both human forcing and climate change for the next 25 years suggest that the status of seagrass ecosystems may somewhat improve in some developed countries, because legislation is being rapidly implemented to protect seagrass meadows. The zero loss policy in the USA and Australia (Coles \& Fortes 2001) means that any losses caused by direct human intervention should be compensated by the creation, generally by transplanting, of a similar extent of new seagrass meadow. Indeed, the general public is becoming increasingly aware of the existence of seagrasses and their important services and functions in coastal ecosystems, which can only raise the prospect of implementing conservation management policies further. Tourism, which has often acted in the past as a vector of degradation of coastal ecosystems, is shifting towards a more sustainable perspective and is becoming, in many countries, an agent promoting an improved quality of coastal ecosystems.

Regrettably, legal protection against seagrass losses is only possible where disturbance derives from proximal causes, and difficulties of assigning responsibility for more diffuse impacts imply that these cannot be corrected through a posteriori legal actions. This includes eutrophication-derived seagrass loss, for nutrient inputs are mostly diffuse in nature. Nutrient reduction plans are being implemented in most developed countries, although these seem to have had little impact on the extent of coastal eutrophication, which is likely to expand in the future, although hopefully at a reduced rate, despite efforts to reduce nutrient inputs. Moreover, the trends outlined above only encompass a fraction of the world's nations, where losses over the 20th century have already been large, and include only a modest fraction of the world's coastline and seagrass beds.

The bulk of the extant seagrass meadows are found on the coastline of developing tropical countries, which are experiencing the greatest rate of environmental degradation at present, and will continue to do so in the future. The impacts on seagrass meadows there will derive from land-use changes, particularly deforestation, and the associated siltation of coastal waters and growing nutrient and sewage inputs, as populations, fertilizer use and sewage implementation expand, and the impacts of the rapidly-growing aquaculture operations arise. What the loss will be by the year 2025 remains uncertain, since the total extent of these impacts is as yet unknown. However, the geographic extent of these major impacts can be readily delimited to the developing world, particularly affecting seagrass meadows in South-east Asia, East Africa, and, to a lesser extent, the Caribbean. The coastal areas of other developing regions, such as South America and West Africa, support seagrass meadows that are much more limited in extent, so that the local impacts will affect smaller areas.

Oceania is the only region with a major seagrass belt where losses are expected to be relatively small, due to the enforcement of zero seagrass loss policies and the small population
(29.5 million) relative to the region's coastline $(30663 \mathrm{~km}$, i.e. 968 humans $\mathrm{km}^{-1}$ ) compared at the other extreme to Asia (14 197 humans km ${ }^{-1}$; World Resources Institute 1998). Even so, the coastal zone near Australian cities has already experienced a significant loss (e.g. Cambridge \& McComb 1984; Clarke \& Kirkman 1989), so that seagrasses are considered amongst the most stressed of Australian ecosystems (Kirkman 1992; Kirkman \& Kirkman 2000).

Seagrass meadows in both developed and developing regions will be affected by changes in global processes. The predicted sea-level rise of about $0.5 \mathrm{~cm} \mathrm{yr}^{-1}$ (Mackenzie 1998) implies a further average regression of the global coastline by $12 \mathrm{~m}$ by the year 2025 and therefore important submarine erosion, which should impact seagrass meadows globally. Quantitative models relating coastline regression to submarine erosion and seagrass loss are, however, lacking, so that sensible predictions cannot be formulated. The sea-level rise may be faster than anticipated due to fast ice melt in polar regions, land subsidence, and the release of the fresh water retained in reservoirs reaching the end of their operative lives. Reservoirs presently hold an amount of water equivalent to $7 \mathrm{~cm}$ of sea-level rise (Carter 1988), and most of them will have exceeded their operative lives by the year 2025 . This effect may be compensated by construction of new reservoirs. Submarine erosion may proceed further than expected because of the predicted increased frequency of storms and wave energy in the coastal zone with climate change (Carter 1988; Bijlsma et al. 1996). For similar reasons the consequences of the predicted increase of $0.5^{\circ} \mathrm{C}$ in global temperature by the year 2025 (Mackenzie 1998) cannot be quantitatively formulated, although they are likely to be minor compared to other sources of change. Based on the calculations in Brouns (1994) and Beer and Koch (1996) the elevation of $\mathrm{CO}_{2}$ concentration to almost $400 \mathrm{ppm}$ by the year 2025 may further stimulate seagrass photosynthesis by 10-20\%. In addition, Zimmerman et al. (1997) calculated that this increased photosynthesis may increase the depth limit of seagrasses, which may lead to an expansion in seagrass cover.

The limitations of knowledge are evident from the fact that only qualitative predictions on the status of seagrass ecosystems by year 2025 are possible, because of (1) undefined rates of change in most relevant forcing factors, (2) lack of quantitative dose-response models that predict seagrass response to changes in environmental factors, and (3) absence of a reliable knowledge of the present extent of seagrass ecosystems. Even for responses where quantitative predictions may be formulated, such as the response of seagrass photosynthesis to increasing $\mathrm{CO}_{2}$ concentrations, the forecasts are suspect, for they assume everything else to be held constant. The predictions therefore lose reliability when the plants respond in an integrative manner to multiple simultaneous changes (Chapin et al. 1987), and when these responses may be affected by responses of other components of the complex communities that comprise the seagrass ecosystem. For instance, the positive effect of increased $\mathrm{CO}_{2}$ 
concentrations on seagrasses predicted from photosynthetic rates may be obscured by similar responses by the epiphytes, buffering the seagrass response due to shading. The predicted increase in water temperature may enhance community respiration, resulting in $\mathrm{CO}_{2}$ concentrations higher than predicted if in equilibrium with the atmosphere in some ecosystems. However, enhanced seagrass respiration may also partially offset the possible increased photosynthetic gains. One of the major effects of climate change on terrestrial vegetation is the shift in vegetation ranges with global warming. A shift in the range of seagrass species, involving a displacement of subtropical and tropical species towards higher latitudes, similarly may be expected. This shift should not affect a poleward extension of the range of temperate species, for there is no evidence for temperature-dependence of the latitudinal limit of seagrasses (Hemminga \& Duarte 2000; Duarte et al. 2002). In contrast to terrestrial vegetation, quantitative predictions on the possible shifts in seagrass ranges with global warming are, however, not possible at the moment, since these would be dependent on changes in the oceanic currents and fronts that are themselves difficult to forecast. The response of seagrass ecosystems to climate change integrate partial responses at a number of levels, from physiological to organismal and ecosystem levels, which often act in opposite directions and interact with one another. The complex nature of the responses renders our capacity to reliably predict the response of seagrass ecosystems to climate change weak.

Provided the recent trends and anticipated threats identified, it is clear that the most likely scenario is one of major loss of seagrass ecosystems, although quantitative forecasts cannot be issued. In a scenario of present and future loss of seagrass ecosystems, the question of the reversibility of decline becomes critical, particularly because loss and recovery of seagrass may be also associated with loss and recovery of important associated fauna and resources. The partial recovery of North Atlantic eelgrass populations affected by the wasting disease within a couple of decades (Short \& Wyllie-Echeverria 1996) shows that recovery from certain impacts may be possible. However, this is only so provided that suitable conditions to support seagrass growth are re-established. Yet, the forcing factors identified above as likely to cause seagrass decline by year 2025 are forecasted to increase even further beyond that date so that global-scale seagrass recovery may not even occur within the present century. Whereas recovery is possible for species with fast growth and/or sexual output, such as Halophila spp. and Enhalus acoroides (Hemminga \& Duarte 2000), recovery is slow in slow-growing species relying largely on clonal expansion, like the Mediterranean Posidonia oceanica, where colonization is thought to take place over several centuries (Duarte 1995). In such species, present and future loss will therefore affect many generations to come. Recovery may involve a shift in species composition, towards either fastgrowing, pioneer species, such as Halophila and Halodule spp. (Marbá \& Duarte 1998), and/or species with high repro- ductive outputs, like Enhalus acoroides in the Indo-Pacific region (Duarte et al. 1997a).

\section{CONCLUSIONS AND MANAGEMENT}

Provided the largely qualitative nature of the possible predictions, the future of seagrass ecosystems remains uncertain. However, since their present status is already plagued with problems, and the future global environmental scenario is one of progressive change, the most likely prospect is a mounting global seagrass decline throughout the 21st century. The main threats to seagrass ecosystems on a large scale will continue to derive from human activity, both through direct disruption of the coastal zone, changes in land use and inputs of silt, nutrients and sewage to the coastal zone, as well as diffuse effects of human activity on climate (Figs. 1 and 2). Sea-level rise, in particular, is projected to be, and may already be (e.g. Marbá \& Duarte 1997), a major cause of seagrass decline (Hemminga \& Duarte 2000).

Despite this alarm, knowledge of seagrass ecosystems is still insufficient to even document their possible present and likely future decline. The $600000 \mathrm{~km}^{2}$ area global cover of seagrasses (Charpy-Roubaud \& Sournia 1990) is only a best guess, derived from the application of a few rules of thumb, in contrast with the relatively adequate knowledge on the area cover of other key marine ecosystems that can be observed more easily from space (e.g. mangroves, coral reefs). Knowledge of the present area seagrasses cover globally is uncertain, and the situation is probably not much better for the bulk of the individual nations with an extended coastline. These uncertainties preclude any reliable quantitative forecast of future seagrass cover, and only qualitative forecasts can be formulated based on established trends and expected changes, supported by anecdotal evidence and opportunistic observations.

Remote sensing techniques using optical or acoustic methods allow the monitoring of the surface seagrasses occupy, allowing the detection of seagrass regression or expansion (Kendrick et al. 1999; McKenzie et al. 2001) but cannot resolve changes in the internal density of the vegetated area. There is therefore a need to improve on the capacity to monitor seagrass remotely, such as improvements in acoustic techniques and use of hyperespectral imagerybased tools to discriminate between seagrass and other vegetated sediments. Monitoring programmes, typically based on the assessment of cover and shoot density along transects and quadrats, generally have an associated error greater than $30 \%$ about the mean (Heidelbaugh \& Nelson 1996), making it difficult to reliably detect changes; a reliable assessment of decline may only be possible for losses already amounting to as much as $50-80 \%$. The low power of monitoring techniques implies that most monitoring programmes can only detect a reliable tendency towards seagrass loss when the seagrass meadows monitored have already experienced substantial damage. There is, therefore, an urgent need to design more effective monitoring approaches, capable of 
detecting losses of $10 \%$ or less, as well as to develop early warning indicators of decline. Repeated census of marked shoots in plots may allow such precision for some seagrass species (e.g. Short \& Duarte 2001). Use of reconstruction techniques to assess past seagrass demography (cf. Duarte $e t$ al. 1994) in monitoring programmes has allowed assessment of local tendencies for decline or expansion and the examination of the overall demographic balance of very large seagrass ecosystems (Peterson \& Fourqurean 2001). Yet, even an optimistic analysis clearly indicates that monitoring efforts cannot possibly encompass but a minimum $(<0.01 \%)$ fraction of the world's seagrass extent, although the implementation of seagrass monitoring programmes has increased over the past decades. The information derived from individual monitoring efforts could, however, be used to derive knowledge of trends at larger spatial scales than that encompassed by the individual monitoring efforts if these were networked into a coherent programme. The implementation of coordinated monitoring networks at the national, regional and global scales would prove instrumental to diagnosis of the large-scale status and trends of seagrass ecosystems.

Management practices to address problems affecting seagrass ecosystems once detected are also insufficiently developed, for management intervention often fails to revert an ongoing seagrass decline (e.g. Delgado et al. 1999). The easiest impacts to regulate are those pertaining to direct mechanical effects on seagrass ecosystems, as well as some improvement of seagrass health following regulation of anchoring in recreational areas (e.g. Cabrera National Park, Spain; N. Marbá, C.M. Duarte, M. Holmer, R. Martínez, G. Basterretxea, A. Orfila, A. Jordi \& J. Tintoré, personal communication 2002). Impacts related to changes in water quality are, however, more difficult to alleviate, although some successes have been reported, such as the reversal of seagrass losses following wastewater treatment on the French
Mediterranean coast (Pergent-Martini \& Pascualini 2000). Empirical (e.g. Duarte 1991b) as well as mechanistic (e.g. Gallegos 1994) models relating water quality to seagrass cover have been developed, which can be used to build scenarios of the effectiveness of different management strategies to improve water quality, and have also led to the development of metrics based on seagrass performance to assess water quality (Dennison et al. 1993). Direct management intervention in the proximal, in addition to the ultimate, causes of seagrass decline may be possible, such as intervention on sediment processes. For instance, iron additions to carbonate sediments may help prevent oxygen consumption by sulphide oxidation, possibly alleviating seagrass stress from anoxic sediments with high sulphide concentrations (cf. Hemminga \& Duarte 2000; Chambers et al. 2001). Such direct intervention practices, however, must be based on robust knowledge of the proximal causes of seagrass decline, which requires further research emphasizing experimental tests of mechanisms and predictive models.

Transplanting techniques to restore seagrasses have had mixed success (Fonseca 1992; Kirkman 1992), however, seagrass transplantation is too costly to be implemented at a large scale, which is a particularly critical drawback provided the fact that the most important losses are expected in developing countries. Hence, even though nationwide mangrove afforestation programmes have been implemented in some developing countries such as Thailand (Aksornkoae 1993), similar initiatives for seagrass meadows are as yet not feasible. In addition, seagrass transplantation programmes often require damage to a donor population, thereby reducing the value of transplantation as a management option.

The threats and stresses to seagrass ecosystems are so diverse that management practices are unlikely to be effective unless accompanied by changing public attitudes and awareness (Fig. 3). Hence, the mid- to long-term conservation of seagrass ecosystems must be based on an adequate education

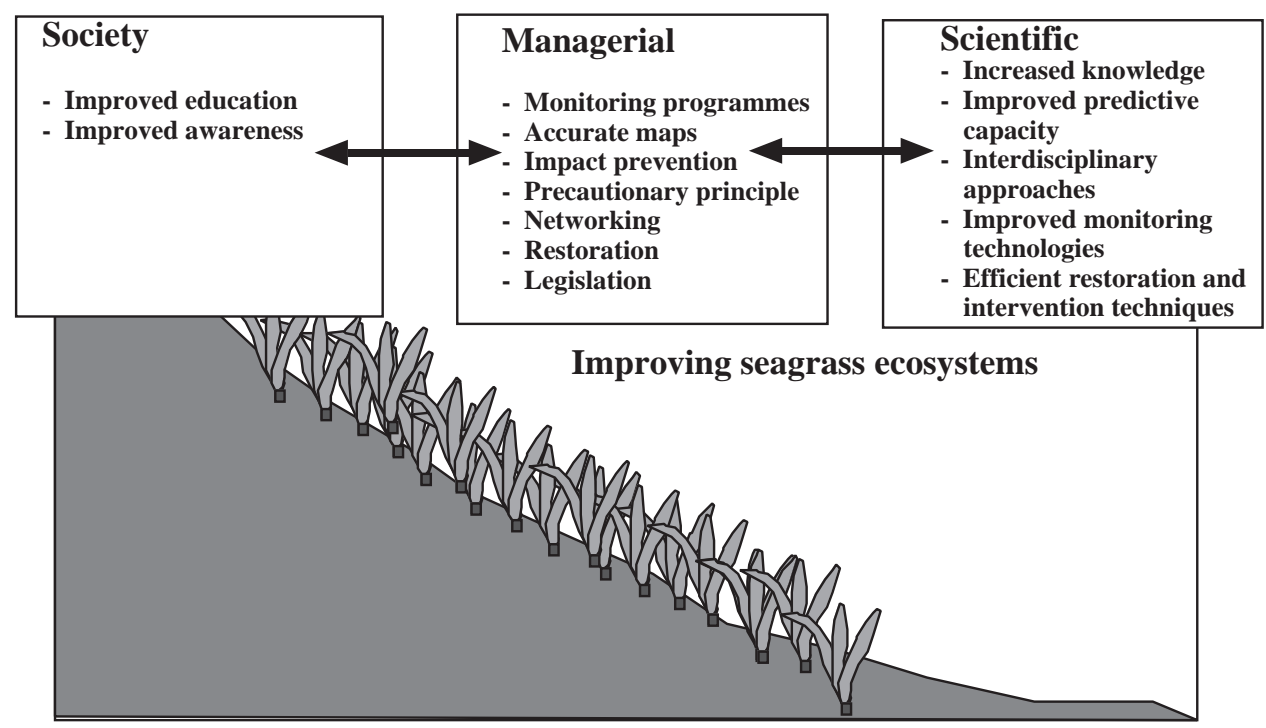

Figure 3 Cooperative elements required to prevent present trend towards seagrass decline and efficiently conserve seagrass ecosystems. 
of the public as to the nature of seagrasses, the functions they perform in nature, and the services these functions provide to society, and on the formulation and dissemination of best management practices to conserve seagrass ecosystems, all of this based on solid, interdisciplinary understanding of seagrass ecology and how to manage the health of seagrass ecosystems (Fig. 3). Education campaigns must, therefore, occupy a prominent place on the agenda for the conservation of seagrass ecosystems (Kirkman \& Kirkman 2000), mobilizing seagrass scientists, managers and environmental educators to convey effectively the importance of seagrass ecosystems and the threats to them. Public awareness alone cannot be effective unless accompanied by sufficient understanding of the causes of stress to seagrass, and how these are integrated at the different levels, from physiological to demographic and landscape scales, to yield responses to possible intervention alternatives. In addition, our capacity to predict seagrass recovery from stress must be developed in order to allow reliable forecasts to be issued. The future of seagrass ecosystems will be largely dictated, therefore, by the social and scientific responses to the challenges ahead.

\section{ACKNOWLEDGEMENTS}

The writing of this paper was supported by the European Commission Managing and Monitoring of Seagrass Beds project (contract \# EVK3-CT-2000-00044). I thank G. Kendrick and G. Harris for valuable discussion, J. Borum, D.I. Walker, J. Fourqurean and N.V.C. Polunin for valuable revisions.

\section{References}

Aksornkoae, S. (1993) Ecology and Management of Mangroves. Bangkok, Thailand: IUCN.

Aragones, L. \& Marsh, H. (2000) Impact of dugong grazing and turtle cropping on tropical seagrass communities. Pacific Conservation Biology 5: 277-288.

Bach, S.S., Borum, J., Fortes, M.D. \& Duarte, C.M. (1998) Species composition and plant performance of mixed seagrass beds along a siltation gradient at Cape Bolinao, the Philippines. Marine Ecology Progress Series 174: 247-256.

Beer, S. \& Koch, E. (1996) Photosynthesis of seagrasses vs. marine macroalgae in globally changing $\mathrm{CO}_{2}$ environments. Marine Ecology Progress Series 141: 199-204.

Bethoux, J.P. \& Copin-Montégut, G. (1986) Biological fixation of atmospheric nitrogen in the Mediterranean Sea. Limnology and Oceanography 31: 1353-8.

Bijlsma, L., Ehler, C.N., Kelin, R.J.L., Kulshrestha, S.M., McLean, R.F., Mimumra, N., Nichols, R.J., Nurse, L.A., Pérez Nieto, H., Stakhiv, E.Z., Turner, K. \& Warrick, R.A. (1996) Coastal zones and small islands. In: Climate Change 1995: Impacts, Adaptations and Mitigation of Climate Change, ed. Intergovernmental Panel on Climate Change, pp. 289-324. Cambridge, UK: Cambridge University Press.

Biliotti, A. \& Abdelahad, N. (1990) Halophila stipulacea (Frossk.) Aschers. (Hydrocharticaeae): éspèce nouvelle pour l'Italie. Posidonia Nemsletter 3: 23-26.
Borum, J. (1996) Shallow waters and land/sea boundaries. In: Eutrophication in Coastal Marine Ecosystems, ed. K. Richardson \& B.B. Jorgensen, pp. 179-203. Washington DC, USA: American Geophysical Union.

Borum, J. \& Sand-Jensen, K. (1996) Is total primary production in shallow coastal marine waters stimulated by nitrogen loading? Oikos 76: 406-10.

Boudouresque, C.F., Charbonel, E., Meinesz, A., Pergent, G., Pergent-Martini, C., Cadiou, G., Bertrandy, M.C., Foret, P., Ragazzi, M. \& Rico-Raimondino, V. (2000) A monitoring network based on the seagrass Posidonia oceanica in the Northwestern Mediterranean Sea. Biologia Marina Mediterranea 7: 328-331.

Brouns, J.J. (1994) Seagrasses and climate change. In: Impacts of Climate Change on Ecosystems and Species: Marine and Coastal Systems, ed. J.C. Pernetta, R. Leemans, D. Elder \& S. Humphrey, pp. 59-71. Gland, Switzerland: IUCN.

Bruun, P. (1962) Sea level rise as a cause of shore erosion. Fournal Waterways Harbours Division, Proceedings American Society Civil Engineering 88: 117-130.

Burt, L. (2001) Evolutionary stasis, contraints, and other terminology describing evolutionary patterns. Biologial fournal of the Linnean Society 72: 509-517.

Cambridge, M.L. \& McComb, A.J. (1984) The loss of seagrasses in Cockburn Sound, Western Australia. I. The time course and magnitude of seagrass decline in relation to industrial development. Aquatic Botany 24: 269-285.

Cancemi, G., De Falco, G. \& Pergent, G. (2000) Impact of a fish farming facility on a Posidonia oceanica meadow. Biologia Marina Mediterranea 7: 341-344.

Carlson, P.R., Yabro, L.A. \& Barber, T.R. (1994) Relationship of sediment sulfide to mortality of Thalassia testudinum in Florida Bay. Marine Science Bulletin 54: 733-746.

Carter, R.W.G. (1988) Coastal Environments. London, UK: Academic Press.

Cebrián, J. \& Duarte, C.M. (1997) Patterns in leaf herbivory on seagrasses. Aquatic Botany 60: 67-82.

Chambers, R.M., Fourqurean, J.W., Macko, S.A., Hoppenot, R. (2001) Biogeochemical effects of iron availability on primary producers in a shallow marine carbonate sediment. Limnology and Oceanography 46: 1278-1286.

Chapin, F.S., III, Bloom, A.J., Field, C.B. \& Waring, R.H. (1987) Plant responses to multiple environmental factors. BioScience 37: 49-87.

Charpy-Roubaud, C. \& Sournia, A. (1990) The comparative estimation of phytoplanktonic and microphytobenthic production in the oceans. Marine Microbial Food Webs 4: 31-57.

Christiansen, C., Christoffersen, H., Dalsgaard, J. \& Norberg, R. (1981) Coastal and nearshore changes correlated with die-back in eelgrass (Zostera marina L.). Sedimentary Geology 28: 163-73.

Clarke, S.M. \& Kirkman, H. (1989) Seagrass dynamics. In: Seagrasses: a Treatise on the Biology of Seagrasses with Special Reference to the Australian Region, ed. A.W.D. Larkum, A.J. McComb \& S.A. Shepherd, pp. 304-34, Amsterdam, the Netherlands: Elsevier.

Cloern, J.E. (2001) Our evolving conceptual model of the coastal eutrophication problem. Marine Ecology Progress Series 210: 223-253.

Cole, J.J., Peierls, B.L., Caraco, N.F. \& Pace, M.L. (1993) Nitrogen loading of rivers as a human-driven process. In: Humans as Components of Ecosystems. ed. M.J. McDowell \& S.T.A. Rickett pp. 141-157. Springer-Verlag. 
Coles, R. \& Fortes, M. (2001) Protecting seagrass - approaches and methods. In: Global Seagrass Research Methods, ed. F.T. Short \& R.G. Coles, pp. 445-463. Amsterdam, the Netherlands: Elsevier. Costanza, R., d'Arge, R., De Groot, R., Fraber, S., Grasso, M., Hannon, B., Limburg, K., Naeem, S., O’Neill, R.V., Paruelo, J., Raskin, R.G., Sutton, P. \& Van den Belt, M. (1997) The value of the world's ecosystem services and natural capital. Nature 387: 253-60.

Dawson, S.P. \& Dennison, W.C. (1996) Effects of ultraviolet and photosynthetically active radiation on five seagrass species. Marine Biology 125: 629-638.

De Iongh, H.H. (1996). Plant-herbivore interactions between seagrasses and dugongs in a tropical small island ecosystem. Ph.D. Thesis, Catholic University Nijmegen, the Netherlands.

De Villéle, X. \& Verlaque, M. (1995) Changes and degradation in a Posidonia oceanica bed invaded by the introduced tropical alga Caulerpa taxifolia in the north western Mediterrnean. Botanica Marina 38: 79-87.

Delgado, O., Grau, A., Pou, S., Riera, F., Massuti, C., Zabala, M. \& Ballesteros, E. (1997) Seagrass regression caused by fish cultures in Fornells Bay, Menorca, western Mediterranean. Oceanologica Acta 20: 557-63.

Delgado, O., Ruiz, J., Pérez, M., Romero, J. \& Ballesteros, E. (1999) Effects of fish farming on seagrass (Posidonia oceanica) in a Mediterranean bay: seagrass decline after organic loading cessation. Oceanologica Acta 22: 109-17.

den Hartog, C. (1970) The Seagrasses of the World. Amsterdam, the Netherlands: North Holland.

den Hartog, C. (1987) 'Wasting disease' and other dynamic phenomena in Zostera beds. Aquatic Botany 27: 3-14.

den Hartog, C. (1994) Suffocation of a littoral Zostera bed by Enteromorpha radiata. Aquatic Botany 47: 21-8.

Dennison, W.C., Orth, R.J., Moore, K.A., Stevenson, J.C., Carter, V., Kollar, S., Bergstrom, P.W. \& Batiuk, R. (1993) Assessing water quality with submersed aquatic vegetation. Bioscience 43: 86-91.

Domning, D.P. (2001) Sirenians, seagrasses, and Cenozoic ecological change in the Caribbean. Palaeogeography, Palaeoclimatology, Palaeoecology 166: 27-50.

Duarte, C.M. (1990) Seagrass nutrient content. Marine Ecology Progress Series 67: 201-207.

Duarte, C.M. (1991a) Allometric scaling of seagrass form and productivity. Marine Ecology Progress Series 77: 289-300.

Duarte, C.M. (1991b) Seagrass depth limits. Aquatic Botany 40: 363-377.

Duarte, C.M. (1995) Submerged aquatic vegetation in relation to different nutrient regimes. Ophelia 41: 87-112.

Duarte, C.M. (1999) Seagrass ecology at the turn of the millennium: challenges for the new century. Aquatic Botany 65: 7-20.

Duarte, C.M. (2001) Seagrass ecosystems. In: Encyclopedia of Biodiversity, Volume 5, ed. S.L. Levin, pp. 255-268. San Diego, USA: Academic Press.

Duarte, C.M. \& Cebrián, J. (1996) The fate of marine autotrophic production. Limnology and Oceanography 41: 1758-66.

Duarte, C.M. \& Chiscano, C.L. (1999) Seagrass biomass and production: a reassessment. Aquatic Botany 65: 159-174.

Duarte, C.M., Marbà, N., Agawin, N.S.R., Cebrián, J., Enríquez, S., Fortes, M.D., Gallegos, M.E., Merino, M., Olesen, B., SandJensen, K., Uri, J. \& Vermaat, J. (1994) Reconstruction of seagrass dynamics: age determinations and associated tools for the seagrass ecologist. Marine Ecology Progress Series 107: $195-209$.
Duarte, C.M., Martínez, R. \& Barrón, C. (2002) Biomass, production and rhizome growth near the northern limit of seagrass (Zostera marina L.) distribution. Aquatic Botany (in press).

Duarte, C.M., Uri, J., Agawin, N.S.R., Fortes, M.D., Vermaat, J.E. \& Marbá, N. (1997a) Flowering frequency of Philippine seagrasses. Botanica Marina 40: 497-500.

Duarte, C.M., Terrados, J., Agawin, N.S.W., Fortes, M.D., Bach, S. \& Kenworthy, W.J. (1997b) Response of a mixed Philippine seagrass meadow to experimental burial. Marine Ecology Progress Series 147: 285-294.

Enríquez S., Duarte, C.M. \& Sand-Jensen, K. (1993) Patterns in decomposition rates among photosynthetic organisms: the importance of detritus C:N:P content. Oecologia 94: 457-471.

European Environmental Agency (1999) State and Pressures of the Marine and Coastal Mediterranean Environment. Luxembourg: European Environmental Agency.

Fonseca, M.S. (1992) Restoring seagrass systems in the United States. In: Restoring the Nation's Marine Environment, ed. G.W. Thayer, pp. 79-110. College Park, Maryland, USA: Maryland Sea Grant College.

Foundation for Environmental Conservation (2001) An introduction to long-term environmental trends [WWW document]. URL http://www.ncl.ac.uk/icef

Fourqurean, J.W. \& Robblee, M.B. (1999) Florida Bay: a history of recent ecological changes. Estuaries 22: 345-357.

Francour, P., Bouderesque, C.F., Harmelin, J.G., HarmelinVivien, M.L. \& Quignard, J.P. (1994) Are the Mediterranean waters becoming warmer: information from biological indicators. Marine Pollution Bulletin 28: 523-526.

Gacia, E. \& Duarte, C.M. (2001) Elucidating sediment retention by seagrasses: sediment deposition and resuspension in a Mediterranean (Posidonia oceanica) meadow. Estuarine Coastal and Shelf Science 52: 505-514.

Gallegos, C.L. (1994) Refining habitat requirements of submersed aquatic vegetation: role of optical models. Estuaries 17: 187-199.

Glémarec, M. (1979) Les fluctuations temporelles des peuplements benthiques liées aux fluctuations climatiques. Oceanologica Acta 2: 365-71.

Harrison, P.G. (1989) Detrital processing in seagrass systems: a review of factors affecting decay rates, remineralization and detritivory. Aquatic Botany 23: 263-288.

Hauxwell, J., Cebrián, J., Furlong, C., Valiela, I. (2001) Macroalgal canopies contribute to eelgrass (Zostera marina) decline in temperate estuarine ecosystems. Ecology 82: 1007-1022.

Heck, K.L., Pennock, J.R., Valentine, J.F., Cohen, L.D. \& Sklenar, S.A. (2000) Effects of nutrient enrichment and small predator density on seagrass ecosystems: an experimental assessment. Limnology Oceanography 45: 1041-1057.

Heidelbaugh, W.S. \& Nelson, W.G. (1996) A power analsis of methods for assessment of change in seagrass cover. Aquatic Botany 53: 227-233.

Hein, M., Pedersen, M.F. \& Sand-Jensen, K. (1995) Size-dependent nitrogen uptake in micro- and macroalgae. Marine Ecology Progress Series 118: 247-253.

Hemminga, M. \& Duarte, C.M. (2000) Seagrass Ecology. Cambridge, UK: Cambridge University Press.

Independent World Commission on the Oceans (1998) The Ocean. Our Future. Cambridge, UK: Cambridge University Press.

Jackson, J.B.C. (2001) What was natural in the coastal ocean? Proceedings of the National Academy of Sciences USA 98: 5411-5418.

Jackson, J.B.C., Kirby, M.X., Berger, W.H., Bjorndal, K.A., 
Botsford, L.W., Bourque, B.J., Bradbury, R.H., Cooke, R., Erlandson, J., Estes, J.A., Hughes, T.P., Kidewell, S., Lange, C.B., Lenihan, H.S., Pandolfi, J.M., Peterson, C.H., Steneck, R.S., Tegner, M.J. \& Warner, R. (2001) Historical overfishing and the recent collapse of coastal ecosystems. Science 293: 629-638.

Jaubert, J.M., Chisholm, J.R.M., Ducrort, D., Ripley, H.T., Roy, L. \& Passeron-Seitre, G. (1999) No deleterious alterations in Posidonia beds in the Bay of Menton (France) eight years after Caulerpa taxifolia colonization. Fournal of Phycology 35: 1113-1119.

Jorgensen, B.B. (1996) Material flux in the sediment. In: Eutrophication in Coastal Marine Ecosystems, ed. K. Richardson \& B.B. Jorgensen, pp. 115-135. Washington DC, USA: American Geophysical Union.

Kendrick, G.A., Eckersley, J. \& Walker, D.I. (1999) Landscapescale changes in seagrass distribution over time: a case study from Success Bank, Western Australia. Aquatic Botany 65: 293-309.

Kirkman, H. (1992) Large-scale restoration of seagrass meadows. In: Restoring the Nation's Marine Environment, ed. G.W. Thayer, pp. 111-140. College Park, Maryland, USA: Maryland Sea Grant College.

Kirkman, H. \& Kirkman, J.A. (2000) The management of seagrasses in South East Asia and Australia. Biologia Marina Mediterranea 7: 305-319.

Kleypas, J. A., Buddemeier, R. W., Archer, D., Gattuso, J.-P., Langdon, C. \& Opdyke, B. N. (1999) Geochemical consequences of increased atmospheric $\mathrm{CO}_{2}$ on coral reefs. Science 284: 118-120.

Koch, E.W. (2001) Beyond light: physical, geological and geochemical parameters as possible submersed aquatic vegetation habitat requirements. Estuaries 24: 1-17.

Mackenzie, F.T. (1998) Our Changing Planet. Second edition. Upper Saddle River, NJ, USA: Prentice Hall.

Marbà, N. \& Duarte, C.M. (1995) Coupling of seagrass (Cymodocea nodosa) patch dynamics to subaqueous dune migration. Fournal of Ecology 83: 381-389.

Marbá, N. \& Duarte, C.M. (1997) Interannual changes in seagrass (Posidonia oceanica) growth and environmental change in the Spanish Mediterranean littoral. Limnology and Oceanography 42: 800-810.

Marbá, N. \& Duarte, C.M. (1998) Rhizome elongation and seagrass clonal growth. Marine Ecology Progress Series 174: 269-280.

Marbá, N., Duarte, C.M., Cebrián, J., Enríquez, S., Gallegos, M.E., Olesen, B. \& Sand-Jensen, K. (1996) Growth and population dynamics of Posidonia oceanica on the Spanish Mediterranean coast: elucidating seagrass decline. Marine Ecology Progress Series 137: 203-213.

Mateo, M.A., Romero, J., Pérez, M., Littler, M.M. \& Littler, D.S. (1997) Dynamics of millenary organic deposits resulting from the growth of the Mediterranean seagrass Posidonia oceanica. Estuarine Coastal Shelf Science 44: 103-110.

McKenzie, L.J., Finkbeiner, M.A. \& Kirkman, H. (2001) Methods for mapping seagrass distribution. In: Global Seagrass Research Methods, ed. F.T. Short \& R.G. Coles, pp. 101-121. Amsterdam, the Netherlands: Elsevier.

Medina, J.R., Tintoré, J. \& Duarte, C.M. (2001) Las praderas de Posidonia y la regeneración de playas. Revista de Obras Públicas 3409: 31-43.

Meinesz, A. \& Hesse, B. (1991) Introduction et invasion de l'algue Caulerpa taxifolia en Méditerranée nord-occidentale. Oceanologica Acta 14: 415-426.
Menzies, R.J., Zaneveld, J.S. \& Pratt, R.M. (1967) Transported turtle grass as a source of organic enrichment of abyssal sediments off North Carolina. Deep-Sea Research 14: 111-2.

Miliman, J.D. \& Meade, R.H. (1993) World-wide delivery of river sediment to the oceans. Fournal of Geology 91: 1-21.

Nakaoka, M. \& Aioi, K. (1999) Growth of the seagrass Halophila ovalis at dugong trails compared to existing within-patch variation in a Thailand intertidal flat. Marine Ecology Progress Series 184: $97-103$.

Nixon, S.W. (1995) Coastal marine eutrophication: a definition, social causes, and future concerns. Ophelia 41: 199-219.

Nixon, S.W., Ammerman, J., Atkinson, L., Berounsky, V., Billen, G., Boicourt, W., Boynton, W., Church, T., DiToro, D., Elmgren, R., Garber, J., Giblin, A., Jahnke, R., Owens, N., Pilson, M.E.Q. \& Seitzinger, S. (1996) The fate of nitrogen and phosphorus at the land-sea margin of the North Atlantic Ocean. Biogeochemistry 35: 141-180.

Nienhuis, P.H., De Bree, B.H.H., Herman, P.M.J., Holland, A.M.B., Verschuure, J.M. \& Wessel, E.G.J. (1996) Twenty five years of changes in the distribution and biomass of eelgrass, Zostera marina, in Grevelingen Lagoon, The Netherlands. Netherlands fournal of Aquatic Ecology 30: 107-17.

Ochieng, C.A. \& Erftemeijer, P.L.A. (1999) Accumulation of seagrass beach cast along the Kenyan coast: a quantitative assessment. Aquatic Botany 65: 221-238.

Olesen, B. (1996) Regulation of light attenuation and eelgrass Zostera marina depth distribution in a Danish embayment. Marine Ecology Progress Series 134: 187-94.

Olesen, B. (1999) Reproduction in Danish eelgrass (Zostera marina L.) stands: size-dependence and biomass partitioning. Aquatic Botany 65: 209-219.

Paerl, H.W. (1995) Coastal eutrophication in relation to atmospheric nitrogen deposition: current perspectives. Ophelia 41: 237-259.

Pascualini, V., Pergent-Martini, C. \& Pergent, G. (1999) Environmental impact identification along the Corsican coast (Mediterranean sea) using image processing. Aquatic Botany 65: 311-320.

Pedersen, O., Borum, J., Duarte, C.M. \& Fortes, M.D. (1998) Oxygen dynamics in the rhizosphere of Cymodocea rotundata. Marine Ecology Progress Series 169: 283-288.

Pergent-Martini, C. \& Pascualini, V. (2000) Seagrass population dynamics before and after the setting up of a wastewater treatment plant. Biologia Marina Mediterranea 7: 405-408.

Pergent, G., Mendez, S., Perget-Martini, C. \& Pascualini, V. (1999) Preliminary data on the impact of fish farming facilities on Posidonia oceanica meadows in the Mediterranean. Oceanologica Acta 22: 95-107.

Peterson, B.J. \& J.W. Fourqurean (2001) Large-scale patterns in seagrass (Thalassia testudinum) demographics in south Florida. Limnology and Oceanography 46: 1077-1090.

Poiner, I.R., Walker, D.I. \& Coles, R.G. (1989) Regional studies seagrasses of tropical Australia. In: Biology of Seagrasses, ed. A.W.D Larkum, A.J. McComb \& S.A. Shepherd, pp. 279-303. Amsterdam, the Netherlands: Elsevier.

Preen, A. (1995) Impacts of dugong foraging on seagrass habitats: observational and experimental evidence for cultivation grazing. Marine Ecology Progress Series 124: 201-13.

Preen, A.R., Lee Long, W.J. \& Coles, R.G. (1995) Flood and cyclone related loss, and partial recovery, of more than $1000 \mathrm{~km}^{2}$ of seagrass in Hervey Bay, Queensland, Australia. Aquatic Botany 52: 3-17. 
Ramos-Esplá, A., Martínez-Pérez, L., Aranda, A., Guillen, J.E., Sánchez-Jerez, P. \& Sánchez-Lizaso, J.L. (1993) Protección de la praderas de Posidonia oceanica (L.) Delile mediante arrecifes artificiales disuasorios frente a la pesca de arrastre ilegal: el caso de El Campello (SE Ibérico). Publicaciones Especiales Instituto Español Oceanografia 11: 431-439.

Reusch, T.B.H., Borström, C., Stam, W.T. \& Olsen, J.L. (1999) An ancient eelgrass clone in the Baltic. Marine Ecology Progress Series 183: 301-304.

Robblee, M.B., Barber, T.R., Carlson, P.R. Jr, Durako, M.J., Fourqurean, J.W., Muehlstein, L.K., Porter, D., Yarbro, L.A., Zieman, R.T. \& Zieman, J.C. (1991) Mass mortality of the tropical seagrass Thalassia testudinum in Florida Bay (USA). Marine Ecology Progress Series 71: 297-9.

Sand-Jensen, K. \& Borum, J. (1991) Interactions among phytoplankton, periphyton, and macrophytes in temperate freshwaters and estuaries. Aquatic Botany 41: 137-76.

Short, F.T. \& Burdick, D.M. (1996) Quantifying seagrass habitat loss in relation to housing development and nitrogen loading in Waquoit Bay, Massachusetts. Estuaries 19: 730-739.

Short, F.T. \& Duarte, C.M. (2001) Methods for the measurement of seagrass growth and production. In: Global Seagrass Research Methods, ed. F.T. Short \& R.G. Coles, pp: 155-182. Amsterdam, the Netherlands: Elsevier.

Short, F.T. \& Neckles, H.A. (1999) The effects of global climate change on seagrasses. Aquatic Botany 63: 169-196.

Short, F.T. \& Wyllie-Echeverria, S. (1996) Natural and humaninduced disturbance of seagrasses. Environmental Conservation 23: $17-27$.

Terrados, J. \& Duarte, C.M. (1999) Experimental evidence of reduced particle resuspension within a seagrass (Posidonia oceanica L.) meadow. Fournal of Experimental Marine Biology and Ecology 243: 45-53.

Terrados, J., Duarte, C.M., Fortes, M.D., Borum, J., Agawin, N.S.R., Bach, S., Thampanya, U., Kamp-Nielsen, L., Kenworthy, W.J., Geertz-Hansen, O. \& Vermaat, J. (1998)
Changes in community structure and biomass of seagrass communities along gradients of siltation in SE Asia. Estuarine, Coastal and Shelf Science 46: 757-768.

Terrados, J., Duarte, C.M., Kamp-Nielsen, L., Borum, J., Agawin, N.S.R., Fortes, M.D., Gacia, E., Lacap, D., Lubanski, M. \& Greve, T. (1999) Are seagrass growth and survival affected by reducing conditions in the sediment? Aquatic Botany 65: 175-197.

UNEP (1989) State of the Mediterranean Marine Environment. Athens, Greece: MAP Technical Report Series, Volume 28.

Van Katwijk, M.M., Vergeer, L.H.T., Schmitz, G.H.W. \& Roelofs, J.G.M. (1997) Ammonium toxicity in eelgrass Zostera marina. Marine Ecology Progress Series 157: 159-73.

Vidal, M., Duarte, C.M. \& Sánchez, M.C. (1999) Coastal eutrophication research in Europe: progress and imbalances. Marine Pollution Bulletin 38: 851-854.

Vitousek, P.M., Mooney, H.A., Lubchenco, J. \& Melillo, J.M. (1997) Human domination of Earth's ecosystems. Science 277: 494-499.

Walker, D.I., Lukatelich, R.J., Bastyan, G. \& McComb, A.J. (1989) Effect of boat moorings on seagrass beds near Perth, Western Australia. Aquatic Botany 36: 69-77.

World Resources Institute (1998) World Resources 1998-99. Oxford, UK: Oxford University Press: 369 pp.

Young, P.C. (1978) Moreton Bay, Queensland: a nursey area for juvenile penaeid prawns. Australian Fournal Marine Freshmater Research 29: 55-57.

Zieman, J.C., Fourqurean, J.W., Frankovich, T.A. (1999) Seagrass dieoff in Florida Bay (USA): long-term trends in abundance and growth of turtle grass, Thalassia testudinum. Estuaries 22: $460-470$.

Zieman, J.C., Iverson, R.L. \& Ogden, J.C. (1984). Herbivory effects on Thalassia testudinum leaf growth and nitrogen content. Marine Ecology Progress Series 15: 151-8.

Zimmerman, R.C., Kohrs, D.G., Steller, D.L. \& Alberte, R.S. 1997. Impacts of $\mathrm{CO}_{2}$ enrichment on productivity and light requirements of eelgrass. Plant Physiology 115: 599-607. 